\title{
The Action of Virginiamycin on Nucleic Acid and Protein Synthesis in Bacillus subtilis Infected with Bacteriophage 2C
}

\author{
By C. COCITO \\ Laboratory of Molecular Genetics, Rega Institute, \\ University of Louvain, Belgium
}

(Accepted for publication 27 March 1969)

\begin{abstract}
SUMMARY
Addition of virginiamycin $\mathrm{M}$ or $\mathrm{S}$ before the virulent phage $2 \mathrm{C}$ prevented Bacillus subtilis from lysing, and this effect was increased roo-fold by simultaneous addition of both factors. When the antibiotics were administered at the end of the eclipse phase, the viral cycle was shortened by virginiamycin $S$, prolonged by factor $M$ and halted by the two inhibitors together. Virginiamycins also prevented the accumulation of phage particles by inhibiting the synthesis of viral precursors during the eclipse period as well as during the maturation phase.

Synthesis of cellular macromolecules was decreased (not suppressed) in Bacillus subtilis after infection with phage $2 \mathrm{C}$, and the degree of repression was a function of the input multiplicity. Viral inhibition of thymidine and uridine incorporation into host DNA and RNA was prevented when virginiamycin was added before infection but unaffected when addition was made at the end of the eclipse phase. Virus and virginiamycin had additive non-overlapping effects on protein synthesis. Moreover, virginiamycins interfered with the function, not the formation, of RNA pulse-labelled after infection, and prevented its decay.

It can be concluded that virginiamycin blocks $(a)$ the preferential translation of viral message, $(b)$ the mechanism by which virus halts host-macromolecule formation, and $(c)$ the synthesis of viral DNA. This can be explained by an inhibitory action of virginiamycin on the synthesis and function of virus-dictated proteins.
\end{abstract}

\section{INTRODUCTION}

Virginiamycin, an inhibitor of mycotic origin, contains two factors, $M$ and $S$ (Vanderhaeghe, van Dijck, Parmentier \& De Somer, I957; Vanderhaeghe \& Parmentier, 1960), which have a synergistic action in the sensitive bacterial strains. In the accompanying paper (Cocito, 1969) evidence is presented that virginiamycins block protein biosynthesis in Bacillus subtilis by interfering with polypeptide chain formation at the level of translation. The process of transcription is not inhibited by the antibiotic, the alterations observed in the metabolism of nucleic acids being due to interference with the process of protein formation.

The aim of the present investigation was to gather additional information about the mechanism of virginiamycin activity in bacteria. Virus-infected cells, in which numerous metabolic patterns are blocked and some others magnified, offer obvious advantages for this type of study. The system used, that of the DNA-containing 
bacteriophage $2 \mathrm{C}$ and its host Bacillus subtilis, bears some peculiar biochemical features, which will be described elsewhere: unlike the well-known Escherichia coli $\mathrm{T} 2$ system (see Cohen, 1963), but similar to $E$. coli $\mathrm{C}$ infected with phage $\phi \mathrm{X}_{174}$ (Ruckert \& Zillig, 1962) Bacillus subtilis infected with the virulent phage $2 \mathrm{C}$ continues forming, though at decreased rate, most of its macromolecules during the first $13 \mathrm{~min}$. of the cycle (eclipse phase). Such biosyntheses become progressively decreased as the maturation progresses and progeny viral DNA accumulates. The onset of lysis (40 to $60 \mathrm{~min}$. after infection) and the degree of inhibition of host macromolecule formation depend on the multiplicity of infection, a situation comparable to that recently described in Shigella dysenteriae infected with phage T 4 (Terzi, 1967).

\section{METHODS}

Abbreviations used: HMU = hydroxymethyluracil; p.f.u. = plaque forming units. Additional abbreviations are listed in the accompanying paper (Cocito, 1969).

Host cells. The following strains of Bacillus subtilis were used: (I) I68/6, wild type; (2) $168 / 2$, leu$^{-}, \operatorname{trp}^{-}$; (3) A 26, U-, $\operatorname{trp}^{-}$; (4) W23, $\mathrm{T}^{-}$, leu-, $\operatorname{trp}^{-}$; (5) 6633, wild type. Bacillus subtilis was plated on $\mathrm{L}$ agar at $37^{\circ}$ for viable counts; for microscope counts infected bacteria were fixed and stained in a suitable dilution with a solution $5 \%$ iodine in $10 \%(\mathrm{w} / \mathrm{v}) \mathrm{KI}$.

The composition of the media used for growing stocks and labelling cells is reported in the accompanying paper (Cocito, 1969).

Virus production, purification and titration. Routinely, phage stocks were produce either on $\mathrm{I} 68 / 2$ or on $\mathrm{A} 26$. Bacteria growing exponentially in $\mathrm{L}$ medium were infected with I to $5 \times 10^{8}$ particles $/ 10^{8}$ bacteria $/ \mathrm{ml}$. Cultures were shaken at $37^{\circ}$ until lysis occurred. Lysates were centrifuged at $9000 \mathrm{~g}$ for $15 \mathrm{~min}$. to remove cell debris, and phage particles were sedimented for $30 \mathrm{~min}$. at $15,000 \mathrm{~g}$. Particles were suspended either in $0.15 \mathrm{M}-\mathrm{NaCl}$ buffered at $\mathrm{pH} 7.4$ with $0.0 \mathrm{I} \mathrm{M}$-tris and containing $40 \mu \mathrm{g}$. serum albumin $/ \mathrm{ml}$. ( ${ }^{32} \mathrm{P}$ experiment), or in the same solution with $0.05 \mathrm{M}$-phosphate buffer ( $\mathrm{pH} 7 \cdot 4)$ replacing the tris $\left({ }^{3} \mathrm{H}\right.$ and ${ }^{14} \mathrm{C}$ experiments). Concentrated phage was purified through two cycles of low- and high-speed centrifugations, followed by centrifugation for $32 \mathrm{hr}$ at $33,000 \mathrm{rev} . / \mathrm{min}$. at $12^{\circ}$ in $\mathrm{CsCl}\left(\rho_{25^{\circ}}=1.52 \mathrm{~g} . / \mathrm{ml}\right.$. $)$ using the $\mathrm{SW} 39$ rotor of a Spinco preparative centrifuge. The band of virus was collected and stored at $4^{\circ}$ after addition of I to $5 \%(v / v)$ of dimethylsulphoxide (Yehle \& Doi, 1965). Exponentially growing bacteria were used as indicator strains for titrating phage by plaque assay. Taking the number of plaques in $168 / 2$ as 100 , the relative efficiency of plating was on the average $65 \%$ for A 26 and $75 \%$ for $168 / 6$.

Disruption of infected host bacteria. Titration of intracellular virus was carried out on enzymic lysates of host bacteria. Metabolism was stopped by transferring samples of the suspension to an ice bath and adding $\mathrm{KCN}$ (0.0 I M). After addition of $10 \mu \mathrm{g}$. lysozyme $/ \mathrm{ml}$., the samples were incubated for $20 \mathrm{~min}$. at $37^{\circ}$, and then diluted with ice cold DSP (0.15 M-NaCl, 0.0 I M-K phosphate buffer ( $\mathrm{pH}_{7.5}$ ) containing $0.5 \mathrm{mg}$. peptone $/ \mathrm{ml}$.). Other procedures for release of infectious intracellular virus, such as lysis with lysozyme in the presence of chloroform $(\mathrm{I} / \mathrm{IO}, \mathrm{v} / \mathrm{v})$ and disruption in a French press of bacteria suspended in $0.0 \mathrm{I} \mathrm{M-NaN}$, had lower efficiency ( 15 to $75 \%$ ) as compared to the $\mathrm{KCN}+$ lysozyme procedure.

For isolation of nucleic acids, bacteria were collected and disrupted in a French 
press as detailed by Cocito (I969). Bacteria were suspended in $0 \cdot \mathrm{I} \mathbf{M}-\mathrm{NaCl}+0 \cdot \mathrm{I}$ M-tris

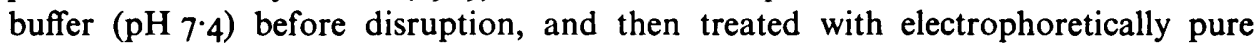
DNAse (I to $5 \mu \mathrm{g}$. $/ \mathrm{ml}$.) at $4^{\circ}$ to $23^{\circ}$ for 5 to $10 \mathrm{~min}$. Enzymic reaction was stopped by addition of $0.5 \%(\mathrm{w} / \mathrm{v}) \mathrm{SDS}$.

Biochemical and biophysical determinations. Methods for colorimetric, radioactivity and spectrophotometric determinations, and procedures for extraction, fractionation and measurement of nucleic acids, were described by Cocito (1969), where preparation of crystalline virginiamycins and the source of chemicals is also given.

\section{RESULTS}

Action of virginiamycin on growth and lysis of virus-infected bacteria. Exponentially growing cultures of the sensitive Bacillus subtilis strains (I68/2, A26, I68/6) lysed 40 to $60 \mathrm{~min}$. after infection with the virulent bacteriophage $2 \mathrm{C}$. The length of the latent period was inversely proportional to the multiplicity of infection and the generation time. Turbidimetric tracings indicated that bacteria infected with $I$ to

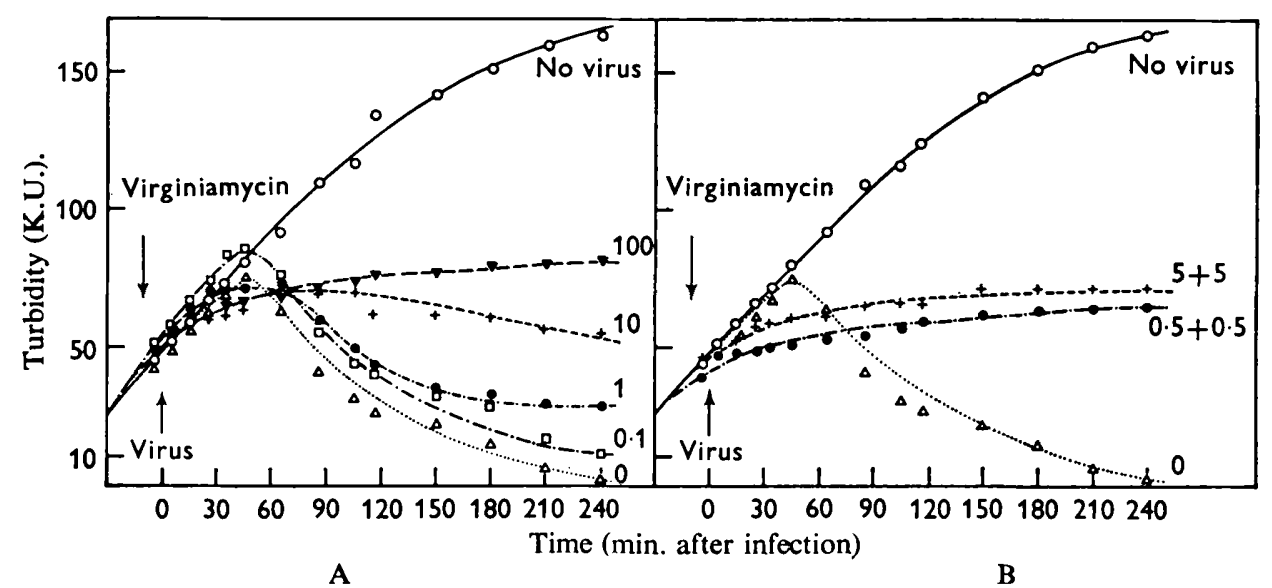

Fig. 1. Growth and lysis of virus-infected Bacillus subtilis in the presence of increasing amounts of virginiamycin. Strain: 168/2. Medium: OS, supplemented with $5 \mathrm{mg}$. Glc, $4 \mu \mathrm{g}$. Trp, $8 \mu \mathrm{g}$. Leu and $800 \mu \mathrm{g}$. ECD $/ \mathrm{ml}$. Infection: input multiplicity of $10 \mathrm{p.f.u}$. of $\mathrm{CsCl}-$ purified virus, added at time 0 to all the cultures but one (control $-\mathrm{O}-$ : no virus, no inhibitors). Virginiamycin (A) $=$ factor $\mathrm{S}(0,0 . \mathrm{I}, \mathrm{I}, 10$, and $100 \mu \mathrm{g} . / \mathrm{ml}$.); (B) $=$ both factors $(0.5$ and $5.0 \mu \mathrm{g} . / \mathrm{ml}$.) added $10 \mathrm{~min}$. before the virus. Growth of the agitated cultures followed turbidimetrically (K.U.).

Io p.f.u. of virus $2 \mathrm{C}$ /bacterium continued growing at the same rate as the controls for the entire eclipse phase (microscope counts of fixed bacteria showed an increase in number). During the maturation phase growth was progressively decreased and then halted; lysis occurred after a stationary phase of about Io min. and was complete.

Increasing amounts of virginiamycins, either separately or together, were added to exponentially growing cultures of Bacillus subtilis 168/2. Bacteria were infected $2 \mathrm{~min}$. later with low multiplicity (Io p.f.u./bacterium) of virus $2 \mathrm{C}$, and the turbidity of the cultures was followed for several generation times. As the concentration of single virginiamycins was increased, the length of the latent period increased; a quite high concentration of the inhibitor was required, however, to block lysis com- 
pletely (Fig. I A). Factors $M$ and $S$ together increased their activity by more than I00-fold since lysis inhibition, which could be obtained with $100 \mu \mathrm{g}$. of single virginiamycins, occurred equally with $0.5 \mu \mathrm{g}$. of their mixture (Fig. I B).

In further experiments virginiamycins were added either before or after the eclipse phase to cultures of Bacillus subtilis I 68/6 infected at high multiplicity (50 to I 50 p.f.u./ bacterium). Under these conditions early and rapid lysis occurred in the controls, whereas lysis was prevented by addition of virginiamycins at the time of infection (Fig. 2 A). When virginiamycin was added at the end of the eclipse period, the latent period was shortened by virginiamycin $S$, and prolonged by factor $M$, whereas the simultaneous addition of both components still prevented lysis completely (Fig. 2B).

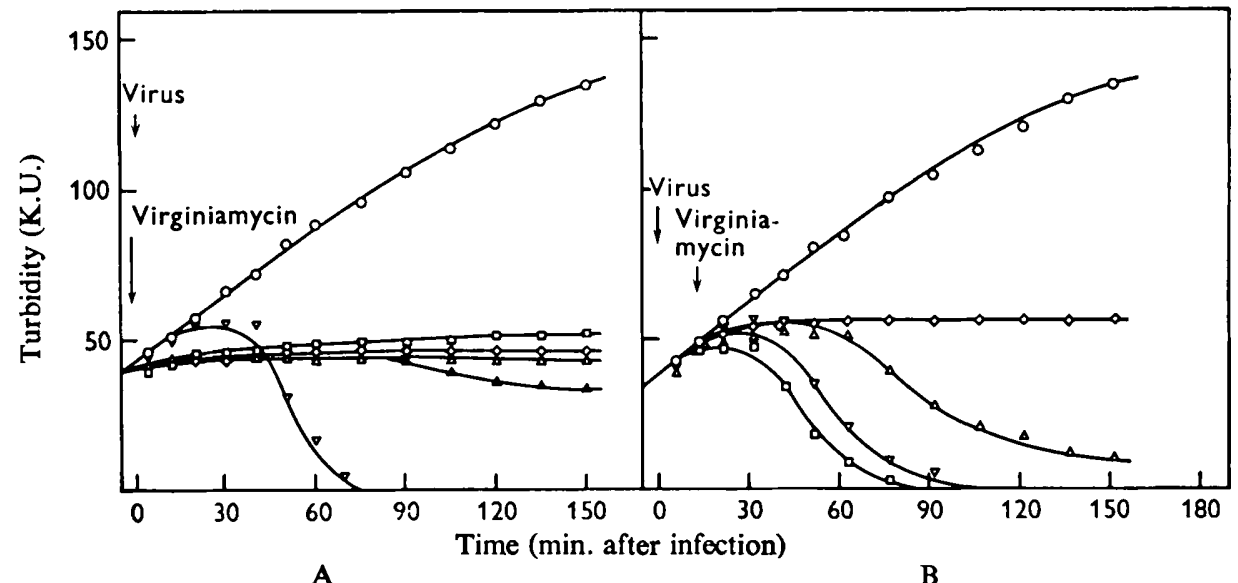

Fig. 2. Relationship between time of addition of virginiamycin and lysis of virus-infected bacteria. Strain: Bacillus subtilis $168 / 6$. Medium: OS, supplemented with $5 \mathrm{mg}$. Glc, and $800 \mu \mathrm{g}$. ECD $/ \mathrm{ml}$. Infection with $50 \mathrm{p}$.f.u. of $\mathrm{CsCl}$-purified virus/bacterium, added at tim o to all the cultures but one (control - $\mathrm{O}-$ : no virus, no inhibitors). (A): virginiamycin added 2 min. before the virus: none $-\nabla-$ (control of infected cells); $50 \mu \mathrm{g}$. factor $\mathrm{M}-\triangle-$; $50 \mu \mathrm{g}$. factor $\mathrm{S}-\square-; 5 \mu \mathrm{g}$. $\mathrm{M}+\mathrm{S} / \mathrm{ml}$. $-\diamond-$. Sample $-\Delta-$ same amount of virginiamycin $M$, but infection with 150 p.f.u./bacterium. (B): virginiamycin (same concentration and symbols) added $15 \mathrm{~min}$. after the virus.

These results indicate that either the synthesis or the function of a phage enzyme, on which lysis of infected organisms depends, was blocked by the simultaneous presence of both virginiamycins, but not by single components, during the maturation phase. However, factors $\mathbf{M}$ and $\mathbf{S}$ separately exerted a full inhibitory activity when their addition was made at the beginning of the eclipse phase.

Formation of viable phage particles in the presence of virginiamycin. Additional information can be obtained by titration of intracellular particles released by artificial lysis from virginiamycin-treated virus-infected bacteria (progeny particles start accumulating intracellularly about $15 \mathrm{~min}$. after infection).

Data reported in Table I show that addition of single virginiamycins before infection halted phage replication: this effect paralleled lysis inhibition. Thus, concentrations of factors $\mathbf{M}$ and $\mathbf{S}$ sufficient to decrease growth of control bacteria by more than $70 \%$ prevented lysis of infected bacteria and stopped production of viral particles. When the level of one virginiamycin was insufficient to prevent lysis, there was only 
limited production of progeny particles. Association of the two virginiamycins at very low concentrations blocked lysis of the host cells and virus formation. In addition, there was a progressive decrease of the number of infectious centres as the time of incubation with the drug increased.

Synthesis of viral DNA in virginiamycin-treated bacteria. In the absence of viable progeny particles, the question can be raised whether the formation of viral DNA is also blocked by the antibiotic. Phage $2 \mathrm{C}$ DNA contains HMU in the place of thymine, which allows viral DNA to be distinguished from host DNA synthesis.

\section{Table I. Formation of viable phage particles in the presence of virginiamycin}

Strain, medium and input multiplicity as for Fig. I. Virginiamycin added Io min. beforo the virus. Samples diluted with ice-cold lysing fluid containing $100 \mu \mathrm{g}$. lysozymo and $0.01 \mathrm{M}-\mathrm{KCN}$, incubated $30 \mathrm{~min}$. at $4^{\circ}$ and $20 \mathrm{~min}$. at $37^{\circ}$, and further diluted in ice-cold DSP. Titration of released virus as outlined in materials and methods, by using Bacillus subtilis $168 / 2$ as indicator strain.

\begin{tabular}{|c|c|c|c|c|c|c|c|c|}
\hline \multirow{3}{*}{$\begin{array}{l}\text { Time of } \\
\text { sampling } \\
\text { (min. after } \\
\text { infection) }\end{array}$} & \multirow{3}{*}{$\begin{array}{c}\text { Control } \\
\text { (no phage; } \\
\text { no } \\
\text { virginia- } \\
\text { mycin) }\end{array}$} & \multicolumn{7}{|c|}{ Phage-infected bacteria } \\
\hline & & \multirow{2}{*}{$\begin{array}{c}\text { No } \\
\text { virginia- } \\
\text { mycin }\end{array}$} & \multicolumn{2}{|c|}{ Factor $\mathbf{M}$} & \multicolumn{2}{|c|}{ Factor $\mathbf{S}$} & \multicolumn{2}{|c|}{$\mathbf{M}+\mathbf{S}$} \\
\hline & & & $(5 \mu \mathrm{g} .)^{*}$ & $(50 \mu \mathrm{g})$. & $(1 \mu \mathrm{g})$. & $(10 \mu \mathrm{g})$. & $(0.1+0.1)^{*}$ & $(I+I)$ \\
\hline \multicolumn{9}{|c|}{ Phage yield $\left(\times 10^{-8}\right.$ p.f.u. $\left./ \mathrm{ml}.\right) \dagger$} \\
\hline $0-10 \$$ & - & $2 \cdot 1$ & I.6 & $2 \cdot 8$ & $2 \cdot 1$ & $2 \cdot 0$ & $2 \cdot 2$ & $1 \cdot 9$ \\
\hline $10-35$ & - & II $\cdot 0$ & $5 \cdot 4$ & $4 \cdot 6$ & $5 \cdot 3$ & $4 \cdot 0$ & $6 \cdot 1$ & $4 \cdot 7$ \\
\hline $35-45$ & - & $17 \cdot 0$ & $3 \cdot 3$ & - & $3 \cdot 8$ & $4 \cdot 5$ & 5.9 & $5 \cdot 0$ \\
\hline $45-55$ & - & $23 \cdot 0$ & $4 \cdot 2$ & $2 \cdot 5$ & $2 \cdot 5$ & $2 \cdot 1$ & $4 \cdot 3$ & $2 \cdot 3$ \\
\hline $55-65$ & - & $36 \cdot 0$ & $8 \cdot 3$ & $2 \cdot 8$ & $2 \cdot 9$ & $I \cdot 7$ & $4 \cdot 7$ & $2 \cdot I$ \\
\hline $65-75$ & - & $48 \cdot 0$ & $9 \cdot 5$ & - & $5 \cdot 0$ & - & 3.6 & - \\
\hline $75-95$ & - & $50 \cdot 0$ & - & $2 \cdot 5$ & $9 \cdot 5$ & - & $3 \cdot 0$ & - \\
\hline $95-125$ & - & - & 13.0 & - & 9.5 & $\mathbf{I} \cdot \mathbf{I}$ & - & I. 5 \\
\hline $125-210$ & - & - & - & $\mathbf{I} \cdot \mathbf{I}$ & - & $1 \cdot 0$ & $2 \cdot 8$ & 0.9 \\
\hline \multicolumn{9}{|c|}{ Turbidity (K.U.670 mp $)$} \\
\hline 30 & 71 & 71 & 60 & 70 & 70 & 69 & $5 I$ & 68 \\
\hline 90 & 104 & 10 & 50 & 75 & 82 & $8 I$ & 67 & 77 \\
\hline 180 & 134 & 2 & 9 & 73 & 9 & 68 & 64 & 90 \\
\hline
\end{tabular}

* $\mu \mathrm{g}$. of single factors added to $\mathrm{I} \mathrm{ml}$. of medium $\mathrm{I}$ min. before the virus.

$\dagger$ Average number of plaques counted in samples taken within the indicated period.

$\S$ Infectious centres titrated upon removal of unadsorbed virus by centrifugation 3 min. after infection.

Virginiamycins $\mathrm{M}$ and $\mathrm{S}$ singly and together were added to the cultures either before or after infection with a high multiplicity of phage $2 \mathrm{C}$. The kinetics of incorporation of $\left[{ }^{3} \mathrm{H}\right]$ uridine into viral DNA was then followed during the viral cycle. Virginiamycins, either singly or together, inhibited the synthesis of viral nucleic acid, and a similar effect was obtained whether addition was made at the beginning (Fig. 3A) or at the end (Fig. 3B) of the eclipse period, when translation of early cistrons had already occurred.

Thus, both virginiamycins specifically block the formation of viral DNA catalyzed by hypothetical virus-specific DNA polymerases. Moreover, since addition of factor S at the end of the eclipse phase prevented viral DNA formation but not cell lysis, we may conclude that lysozyme could be made in the absence of an active synthesis of viral DNA. 
Synthesis of host DNA in the presence of virginiamycin. Virginiamycins inhibit the formation of viral DNA: what is their action on host DNA synthesis in virus-infected bacteria? The problem was investigated by following the kinetics of incorporation of $\left[{ }^{3} \mathrm{H}\right]$ thymidine during the viral cycle (2 C-DNA does not contain thymine). The inhibitors were added to the culture either before or at the end of the eclipse period.

Infection of strain $168 / 6$ at high multiplicity (50 p.f.u./bacterium) inhibited the incorporation of thymidine into host DNA sharply. The degree of inhibition was at least $70 \%$ during the first $5 \mathrm{~min}$. and $85 \%$ during the next $5 \mathrm{~min}$. of the viral cycle, and the amount of thymidine incorporated during the eclipse phase into host cell DNA was no more than Io to $15 \%$ that of control bacteria. Under these conditions addition of virginiamycins before the virus largely prevented the inhibition of host DNA formation: the effect of factor $M$ lasted for the entire viral cycle, whereas that of factor S was limited to the eclipse phase (Fig. 4).

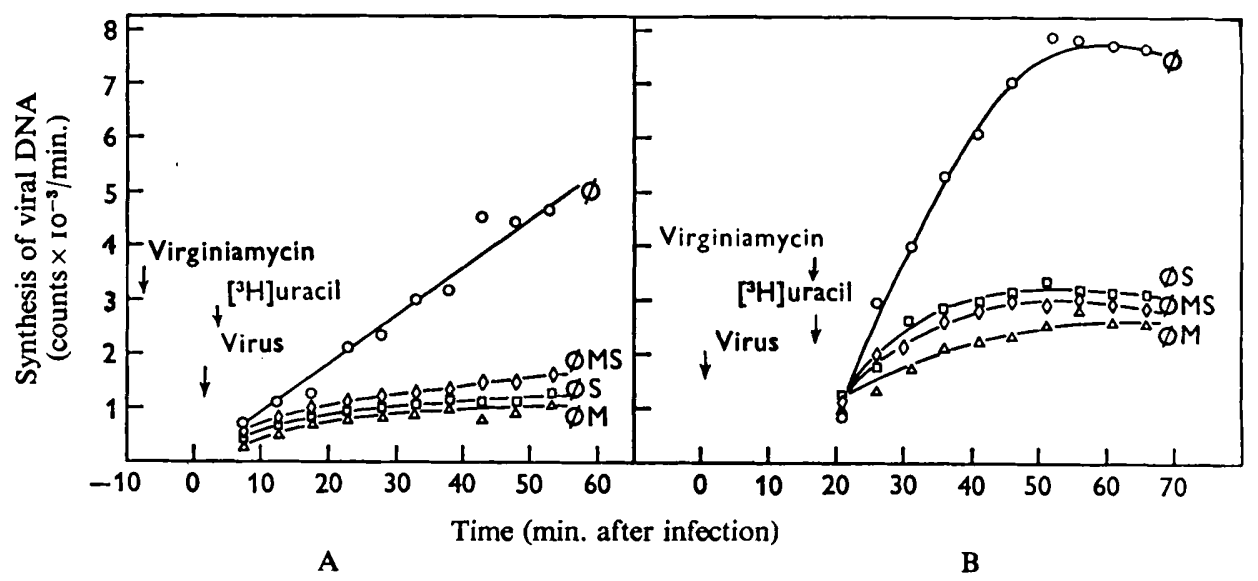

Fig. 3. Formation of viral DNA in the presence of virginiamycins. Strain, medium, and infection as for Fig. 2. (A): $50 \mu \mathrm{g}$. of single virginiamycins, or $2.5 \mu \mathrm{g}$. of both components added $8 \mathrm{~min}$. before the virus. (B): same concentrations of inhibitors added $14 \mathrm{~min}$. after the virus. Labelling: [6- ${ }^{8} \mathrm{H}$ ]uracil, (specific activity $12 \mathrm{c} / \mathrm{mmole}, \mathrm{I} \mu \mathrm{c} / \mathrm{ml}$., f.c.), added either $2 \mathrm{~min}$. after the virus (3A) or 2 min. after virginiamycin (3B). TCA-insoluble radioactivity, precipitated in the presence of $200 \mu \mathrm{g}$. unlabelled uracil and $100 \mu \mathrm{g}$. BSA $/ \mathrm{ml}$., collected on micropore filters. Membranes eluted with $0.5 \mathrm{M}-\mathrm{KOH}$ for $15 \mathrm{~min}$. at $23^{\circ}$ and counted again (to determine the amount of residual radioactivity). Eluates further incubated for $18 \mathrm{hr}$ at $37^{\circ}$ and alkali-resistant TCA-insoluble radioactivity (DNA) collected on micropore filters and counted (Cocito, I969).

Incorporation of amino acids into polypeptides: action of infection and virginiamycin. Since, upon infection, the inhibition of host cell DNA preceded the formation of viral DNA, one may suppose that the latter was not responsible for the former. Inhibition of host cell DNA might be due, instead, to some virus-induced early proteins. If so, one would predict that infection affected protein synthesis far less than formation of host cell DNA, and that virus and virginiamycin will have additive non-overlapping effects on polypeptide chain formation.

This prediction was verified by studying the incorporation of $\left[{ }^{14} \mathrm{C}\right]$ amino acids by Bacillus subtilis infected with phage $2 \mathrm{C}$ and incubated in the presence of virginia- 
mycins. Figure 5 shows that viral infection decreased the incorporation rate, and that the inhibitory effect was magnified when infection was carried out in the presence of virginiamycin. At the end of the eclipse period, for example, amino acid incorporation in virus-infected bacteria was about $10 \%$ that in uninfected bacteria when virginiamycin was present, and $70 \%$ when it was absent.

Comparison of Fig. 5 with data reported in the accompanying paper (Cocito, 1969) shows that the degree of inhibition of protein synthesis by virginiamycin in infected bacteria was about double that in uninfected bacteria. Hence, virus infection and virginiamycin repress protein synthesis through different mechanisms, and their effects are additive.

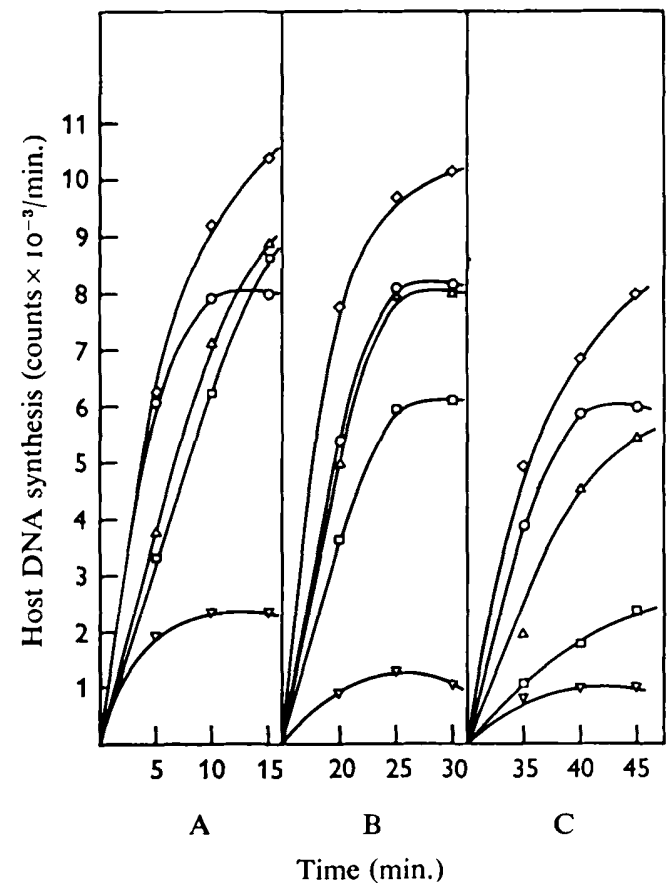

Fig. 4

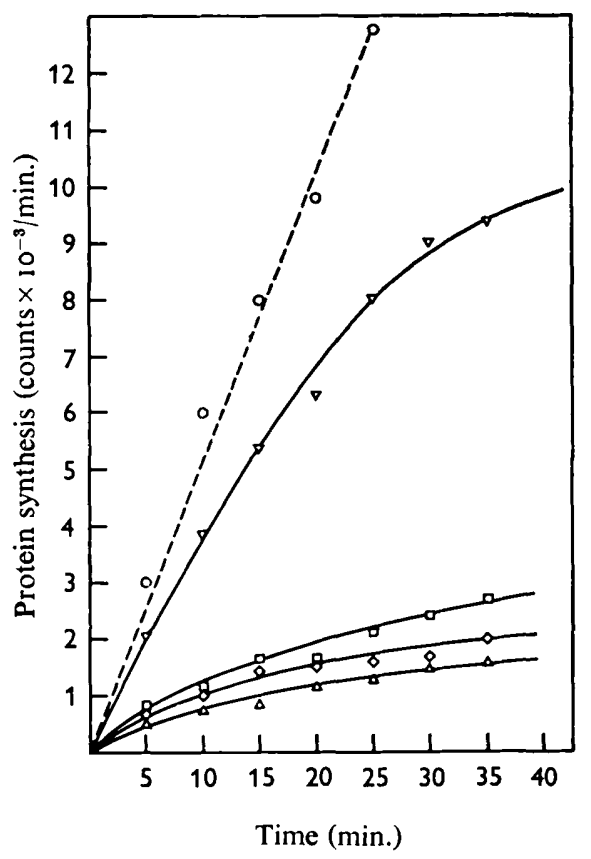

Fig. 5

Fig. 4. Rate of labelling of host DNA in virginiamycin-treated virus-infected bacteria. Strain: Bacillus subtilis $168 / 6$. Medium: OS, supplemented with $5 \mathrm{mg}$. Glc, $800 \mu \mathrm{g}$. ECD/ $\mathrm{ml}$. Virginiamycin: none (control of uninfected bacteria $-\mathrm{O}-$; control of infected bacteria $-\nabla-$ ); $50 \mu \mathrm{g}$. factor $\mathrm{M}-\triangle-$; $50 \mu \mathrm{g}$. factor $\mathrm{S}-\square-; 2.5 \mu \mathrm{g} . / \mathrm{ml}$. of both components $-\diamond-$, added to the cultures $9 \mathrm{~min}$. before infection. Virus: 30 p.f.u./ bacterium added I min. before labelling to all the cultures but one (control $-\mathrm{O}-$ of uninfected bacteria). Labelling: $\left[{ }^{3} \mathrm{H}\right]$ thymidine (specific activity $17 \mathrm{c} / \mathrm{mmole}, 0 \cdot \mathrm{IO}_{4} \mu \mathrm{c} / \mathrm{ml}$., f.c.) added at I (A), I6 (B) and 3I (C) min. after infection. Sampling: every $5 \mathrm{~min}$. for $15 \mathrm{~min}$. TCA-insoluble radioactivity collected on micropore filters in the presence of $100 \mu \mathrm{g}$. unlabelled thymidine and $\mathrm{BSA} / \mathrm{ml}$., and counted.

Fig. 5. Kinetics of incorporation of amino acids into proteins: action of virginiamycin and infection. Strain: Bacillus subtilis A 26. Medium: OS, supplemented with $5 \mathrm{mg}$. Glc, $4 \mu \mathrm{g}$. Trp, $8 \mu \mathrm{g}$. Leu, $800 \mu \mathrm{g}$. ECD and $100 \mu \mathrm{g}$. U/ml. Infection: $30 \mathrm{p} . f . u$. of virus added $9 \mathrm{~min}$. after virginiamycin and I min. before labelling to all the cultures but one. Virginiamycin: none (control of uninfected bacteria - $\mathrm{O}-$; control of infected bacteria $-\nabla-$ ); $50 \mu \mathrm{g}$. factor $\mathrm{M}-\triangle-; 25 \mu \mathrm{g}$. factor $\mathrm{S}-\square-; 2.5 \mu \mathrm{g} . \mathrm{M}+\mathrm{S} / \mathrm{ml}$. $->-$. Labelling: $\left.{ }^{14} \mathrm{C}\right]$ algal protein hydrolysate (specific activity $520.8 \mu \mathrm{c} / \mathrm{mg}$., $0.417 \mu \mathrm{c} / \mathrm{ml}$., f.c.) added at time 0 . TCA-insoluble radioactivity collectod on micropore filters and counted. 


\section{COCITO}

Kinetics of polynucleotide formation in virginiamycin-treated host cells. In uninfected bacteria virginiamycin represses polyribonucleotide and deoxyribonucleotide formation only after protein synthesis has been halted (Cocito, I 969). Since transcription and translation of early viral cistrons occur within a few minutes, it is logical to suppose that the virus would affect host RNA synthesis more rapidly and profoundly than do the virginiamycins. Data which follow show the correctness of this prediction.

Incorporation of labelled uracil into polyribonucleotides was followed in bacteria which were treated first with virginiamycins and then infected with virus $2 \mathrm{C}$. Radio-

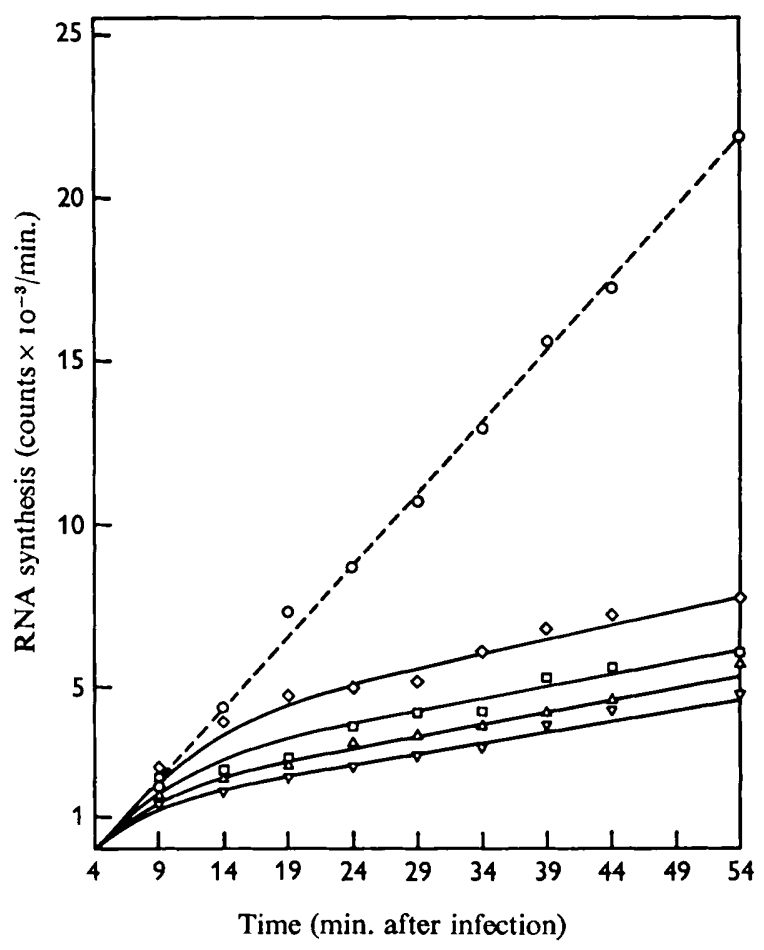

Fig. 6

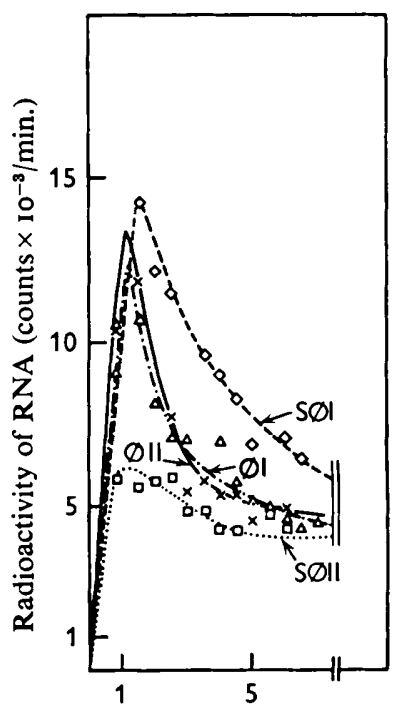

Time (min. after labelling)

Fig. 7

Fig. 6. Incorporation of uracil into polyribonucleotides, after infection with virus $2 \mathrm{C}$ in the presence of virginiamycins. Strain, medium and conditions of infection as for Fig. 5 . Virginiamycins: none (controls of uninfected - $\mathrm{O}-$ and virus-infected $-\nabla-$ bacteria); $50 \mu \mathrm{g}$. factor $\mathrm{M}(-\triangle-), 25 \mu \mathrm{g}$. factor $\mathrm{S}(-\square-), 2.5 \mu \mathrm{g} . \mathrm{M}+\mathrm{S}\left(-\nabla_{-}\right)$, added $4 \mathrm{~min}$. before labelling. Bacteria infected with 30 p.f.u. of virus $2 \mathrm{C} /$ bacterium $4 \mathrm{~min}$. before isotope addition. Labelling: [6- ${ }^{3} \mathrm{H}$ ] uracil (specific activity $12 \mathrm{c} / \mathrm{mmole}, 0.835 \mu \mathrm{c} / \mathrm{ml}$., f.c.) added at time 0 . TCA-insoluble radioactivity precipitated in the presence of $100 \mu \mathrm{g}$. of unlabelled uracil and $100 \mu \mathrm{g}$. BSA $/ \mathrm{ml}$., collected on micropore filters and counted. Values corrected for KOH-resistant radioactivity (see legend for Fig. 3 and Cocito, 1969).

Fig. 7. Decay of pulse-labelled RNA in virginiamycin-treated virus-infected bacteria. Strain and medium as for Fig. I. Virus: 15 p.f.u./bacterium of $\mathrm{CsCl}$-purified $2 \mathrm{C}$ added $1 \mathrm{~min}$. before labelling. Virginiamycins: none (controls of virus-infected bacteria $\emptyset_{1}$ and $\emptyset_{2}$ ); $5 \mu \mathrm{g}$. factors $\mathrm{M}+\mathrm{S}$ added $10 \mathrm{~min}$. before the virus ( $\mathrm{S} \emptyset_{1}$ and $\mathrm{S} \emptyset_{2}$ ). Labelling time (time o): $\left[6-^{3} \mathrm{H}\right]$ uracil (specific activity $\mathrm{I} 2 \mathrm{c} / \mathrm{mmole}, 3.58 \mu \mathrm{c} / \mathrm{ml}$., f.c.) added $8 \mathrm{~min}$. ( $\emptyset_{\mathrm{I}}$ and $\mathrm{S} \emptyset_{\mathrm{I}}$ ) or $23 \mathrm{~min}$. ( $\emptyset_{2}$ and $S \emptyset_{2}$ ) after infection. Chasing (at $45 \mathrm{sec}$.); $200 \mu \mathrm{g}$. of unlabelled uracil and $15 \mu \mathrm{g}$. of actinomycin $\mathrm{D} / \mathrm{ml}$. TCA-insoluble radioactivity precipitated in the presence of $200 \mu \mathrm{g}$. unlabelled uracil and $100 \mu \mathrm{g}$. BSA $/ \mathrm{ml}$., collected on micropore filters and counted. 
activity determinations were corrected for label incorporated into viral DNA. Figure 6 shows that infection with phage $2 \mathrm{C}$ repressed incorporation of uracil very quickly. At the end of the eclipse phase the incorporation rate in infected bacteria was about one third that of uninfected bacteria. The inhibitory effect caused by the virus during the eclipse phase was reduced when infection was carried out in the presence of virginiamycin. This antagonistic action could not be demonstrated during the maturation phase, however, because the blockage of RNA synthesis due to the virginiamycin-mediated halt of protein synthesis (see Cocito, 1969) obscured the whole picture.

Synthesis and decay of pulse-labelled RNA in virus-infected bacteria incubated with virginiamycin. Data reported in the previous sections support the idea that virginiamycins might prevent formation of virus components and block virus-specific biochemical reactions by halting the synthesis and function of virus-dictated proteins. A study of mRNA metabolism would be an approach to this problem.

Virus-infected bacteria were pulse-labelled with $\left[{ }^{3} \mathrm{H}\right]$ uracil in the presence of virginiamycin, and chased $45 \mathrm{sec}$. later with an excess of unlabelled uracil and actinomycin. The use of this inhibitor of transcription for preventing re-incorporation of chased radioactivity in uninfected virginiamycin-treated Bacillus subtilis has been stressed already (Cocito, 1969). Samples of labelled and chased cultures were withdrawn at different times, and the radioactivity incorporated into polyribonucleotides was measured.

Figure 7 shows that virginiamycins interfered with the decay of pulse-labelled RNA, with a consequent increase of the half-life of this RNA. Under our experimental conditions average values of 150 and $240 \mathrm{sec}$. were calculated for the half-lives of early and late messenger viral RNAs (compare these figures with those for host messenger RNA, for which an average value of $90 \mathrm{sec}$. (Cocito, 1969) was reported). It is difficult to calculate exactly the half-life of pulse-RNA in virginiamycin-treated virus-infected bacteria; values of 7 to 12 min. were obtained.

It can be concluded that virginiamycins $M$ and $S$ interfere with the function, not with the synthesis, of pulse-labelled RNA. These findings exclude a block of transcription and predict an alteration of the translation mechanism.

\section{DISCUSSION}

Lysis inhibition of bacteria infected in the presence of virginiamycin is probably due to a blockage of phage enzyme formation. Such an effect can be accounted for by the rapidity with which the antibiotic halts the incorporation of amino acids into polypeptides (see Fig. 5 and Cocito, 1969). Addition of virginiymycin $\mathrm{M}$ or $\mathrm{S}$ at the end of the eclipse phase still prevents the synthesis of viral components, not the lysis of the host cell (Fig. 2 B). The simplest explanation is that mRNA for lysozyme formation is made during the entire viral cycle, its concentration at any given moment being proportional to that of viral template. If so, the amount of lysozyme present at the end of the eclipse phase would be too small for a precise biochemical evaluation (Pene \& Marmur, I 967), yet sufficient to cause the lysis of the host cell at a reduced rate (Fig. 2 B). Such interpretation of data reported in the present work is in perfect agreement with the conclusions drawn by Edlin $(1965 a, b)$ with the $\mathrm{T}_{4}$ Escherichia coli system. 
The observation that virginiamycin, when added before virus $2 \mathrm{C}$, prevents the synthesis of viral precursors, parallels earlier findings with chloramphenicol-treated T 2-infected Escherichia coli (Tomizawa \& Sunakawa, 1956; Hershey \& Melechen, 1957). And this is probably true for all inhibitors of protein synthesis, whether active at the transcriptional or translational level (Cohen, Sekiguchi, Stern \& Barner, I963; Cohen, 1963): when there is a blockage in the translation of the mRNA corresponding to the early cistrons, formation of the enzymes necessary for viral DNA synthesis is prevented. The simplest explanation for the inhibition of viral DNA which occurs when virginiamycins is added at the end of the eclipse phase is that the drug interferes with the function of virus-specific DNA polymerases which are already made by that time. Since the synthesis of host DNA, unlike that of viral DNA, is not altered by virginiamycin (Cocito, I969), one may predict that the antibiotic has completely different actions on host and viral DNA-polymerases.

In Bacillus subtilis infected with virus $2 \mathrm{C}$ the synthesis of host RNA and proteins is only partly repressed, a situation comparable to those recently observed in Shigella dysenteriae infected with phage $\mathrm{T}_{4}$ (Terzi, 1967), and Escherichia coli $\mathrm{C}$ infected with the 'clear' non-lysogenizing mutant of $\lambda$ (Terzi \& Levinthal, 1967). The main difference between $\lambda c$-infected $E$. coli and $2 \mathrm{C}$-infected $B$. subtilis is that, in the former case, a treatment with chloramphenicol before infection, though incapable of preventing the virus-mediated inhibition of uracil incorporation into RNA, suppressed completely amino acid incorporation into proteins (Terzi \& Levinthal, 1967). Conversely, in the latter system, a level of virginiamycin capable of reducing the inhibition of RNA formation due to the virus (Fig. 6) increased still further the repression of protein synthesis caused by infection (Fig. 5). However, such differences between the two virushost systems may not be real, because the experiments were performed with different levels of inhibitors.

Treatment of Escherichia coli with chloramphenicol before infection with phage $\mathrm{T}_{4}$ induces the following alterations of nucleic acid metabolism: (I) rRNA, tRNA and host DNA are synthesized, though at reduced rates with respect to uninfected controls (Nomura, Hall \& Spiegelman, I960; Nomura, Okamoto \& Asano, 1962; Nomura, Matsubara, Okamoto \& Fujimura, 1962); (2) the greater the multiplicity of infection, the higher the degree of inhibition of the host DNA fraction which is formed in the presence of the antibiotic; (3) for every multiplicity, RNA synthesis is inhibited to a greater extent than synthesis of host DNA (Nomura, Witten, Mantei \& Echols, 1966). Some of the results reported in the present paper are similar to those with $\mathrm{T}_{4}$-infected, chloramphenicol-treated Escherichia coli. Virginiamycin added before the virus reduces the inhibition of host DNA synthesis to a greater extent than that of RNA formation (Fig. 4 and 6); this effect does not take place when the antibiotic is added at the end of the eclipse phase.

Kölsh (1965) reported that the synthesis of Escherichia coli DNA is not blocked after infection with u.v.-irradiated phage T 2 : thus, transcription and perhaps translation (Sköld \& Buchanan, 1964; Furth \& Pizer, 1966) of some viral cistrons are responsible for the inhibition of host chromosome replication. The work of Nomura et al. ( 1966$)$ indicates that the $\mathrm{T}_{4}$-mediated inhibition of the synthesis of $E$. coli DNA may be determined as much by a chloramphenicol-sensitive virus-dictated protein as by an unknown chloramphenicol-insensitive mechanism related to the multiplicity of infection. My data agree with these conclusions and, in addition, exclude the possibility 
that replication of viral DNA per se might be responsible for the inhibition of hostDNA, since the formation of the latter is still blocked under conditions which prevent the synthesis of $2 \mathrm{C}$-chromosome.

The half-life of the RNA which is pulse-labelled in bacteria infected in the presence of virginiamycin is prolonged. Similar observations have been made with uninfected bacteria after treatment with the antibiotic (Cocito, 1969). This indicates that virginiamycin interferes with the function, rather than the synthesis, of pulse-labelled RNA, and that the mechanism of action of the antibiotic is similar in uninfected and virusinfected bacteria.

The over-all conclusion is that virginiamycin interferes, not with transcription, but with the translation mechanism of both host and viral mRNA. Some 'early' viral cistrons apparently code for inhibitors (probably proteins) which repress replication and transcription of the host chromosome: they are responsible for the preferential reading of viral message which can be observed in the absence of antibiotics. Virginiamycins prevent the translation of the early viral message, and so mediate a derepression of host macromolecule formation. In addition, virginiamycins specifically inhibit the action of two or more virus-specific enzymes, thus preventing the formation of viable viral particles and their release by lysis of the host cell.

Virus $2 \mathrm{C}$ was isolated by $\mathrm{Dr} \mathrm{J}$. Pène (Yeshiva University) and obtained through the courtesy of Professor J. Marmur (A. Einstein College of Medicine, Bronx, N.Y.). The author is indebted to Prof. H. Vanderhaeghe (University of Louvain) for the gift of inhibitors and to Prof. J. Marmur (Yeshiva University) for hospitality and advice during the preliminary part of this work.

\section{REFERENCES}

Cocrro, C. (1969). Metabolism of macromolecules in bacteria treated with virginiamycin. J. gen. Microbiol. 57, 179.

CoHen, S. S. (1963). The biochemistry of viruses. A. Rev. Biochem. 32, 83.

Cohen, S. S., Sekiguchi, M., Stern, J. L. \& Barner, H. D. (1963). The synthesis of messenger RNA without protein synthesis in normal and phage-infected thymineless strains of Escherichia coli. Proc. natn. Acad. Sci. U.S.A. 49, 699.

EdLIN, G. (1965a). Amino acid regulation of bacteriophage RNA synthesis. J. molec. Biol. 12, 356. EDLIN, G. $(1965 b)$. Gene regulation during bacteriophage T 4 development. J. molec. Biol. 12, 363.

Furth, J. J. \& Pizer, L. J. (1966). Deoxyribonucleic acid-dependent ribonucleic acid synthesis in Escherichia coli infected with bacteriophage T 2. J. molec. Biol. 15, I 24.

HeRshey, A. D. \& Melechen, N. E. (1957). Synthesis of phage-recursor nucleic acid in the presence of chloramphenicol. Virology 3, 207.

KöLSH, E. (1965). Der Einfluss extracellulärer u.v.-Bestrahlung des Phagen T 2 auf die Replikation seiner DNA. II. Das Verhalten der geschädgten Genome in einzelinzisierten Zollen. Z. VererbLehre 96, 175 .

Nomura, M., Hall, B. D. \& Spiegelman, S. (1960). Characterization of RNA synthesized in E. coli after bacteriophage T 2 infection. J. molec. Biol. 2, 306.

Nomura, M., OKamoto, K. \& Asano, K. (1962a). RNA metabolism in $E$. coli infected with bacteriophage $\mathrm{T}_{4}$. Inhibition of host $\mathrm{R}$ RA and tRNA synthesis by phage and effect of chloromycetin. J. molec. Biol. 4, 376.

Nomura, M., Matsubara, K., Okamoto, K. \& Funmura, R. (1962 b). Inhibition of host nucleic acid and protein synthesis by bacteriophage $\mathrm{T}_{4}$ : its relation to the physical and functional integrity of host chromosome. J. molec. Biol. 5, 535. 
Nomura, M., Wirten, C., Mantei, N. \& Echols, H. (I966). Inhibition of host nucleic acid synthesis by bacteriophage $\mathrm{T}_{4}$ : effect of chloramphenicol at various multiplicities of infection. $J$. molec. Biol. 17, 273.

Pene, J. J. \& Marmur, J. (I967). DNA replication and expression of early and late bacteriophage function in B. subtilis. J. Virol. $1,86$.

RUCKeRT, R. R. \& Zillig, W. (I962). Biosynthesis of virus protein in Escherichia coli $\mathrm{c}$ in vivo following infection with bacteriophage $\varnothing X$ 174. J. molec. Biol. $5, \mathrm{I}$.

Sköld, O. \& Buchanan, J. M. (1964). Inhibition of deoxyribonucleic acid-directed ribonucleic acid polymerase in Escherichia coli infection with bacteriophage T4. Proc. natn. Acad. Sci. U.S.A. 51, 553.

TERzI, M. (1967). Studies on the mechanism of bacteriophage T 4 interference with host metabolism. J. molec. Biol. 28, 37.

Terzi, M. \& Levinthal, C. (1967). Effects of n-phage infection on bacterial synthesis. J. molec. Biol. 26, 525 .

Tomizawa, J. \& Sunakawa, S. (1956). The effect of chloramphenicol on deoxyribonucleic acid synthosis and the development of resistance to ultraviolet irradiation in $E$. coli infected with bacteriophage T 2. J. gen. Physiol. 39, 553.

VANDERHaeghe, H. \& Parmentier, G. (I960). The structure of factor S of staphylomycin. J. $\mathrm{Am}$. chem. Soc. 82, $44 \mathrm{I} 4$.

Vanderhaeghe, H., van Dijck, P., Parmentier, G. \& De Somer, P. (1957). Isolation and properties of the components of staphylomycin. Antibiotics Chemother. 3, 606.

YeHLE, C. O. \& DoI, R. H. (1965). Stabilization of B. subtilis phage with dimethyl-sulfoxide. Can. J. Microbiol. II, 745 . 